\title{
Comparison of Angiocatheter and Thorax Tube in the Treatment of Pneumothorax in Newborn Patients
}

\author{
Murat KABAKLIOĞLU 國, Murat KAYA 國
}

\begin{abstract}
Aim: In pneumothorax, which is one of the life-threatening emergencies, early diagnosis and appropriate treatment are important to reduce complications and mortality. Treatment is provided by evacuation of air from the pleural space with underwater drainage using needle thoracentesis or fine catheter and tube thoracostomy techniques.

Material and Methods: Between March 2014 and March 2021, neonatal intensive care unit medical records were retrospectively reviewed, and newborns with pneumothorax were evaluated. Information about drainage methods, duration of treatment, efficacy of treatment and complications were obtained. The patients were divided into two groups. A chest tube was placed in the patients in the first group, and a venous catheter was placed in the patients in the second group.

Results: Pneumothorax was detected in $1.85 \%$ (n:23) of 1242 patients in our neonatal intensive care unit. Eight patients underwent tube thoracostomy and 12 patients underwent underwater sealed drainage with venous catheter, while three patients resolved spontaneously.

Conclusion: Tube thoracostomy in neonatal pneumothorax may lead to serious complications especially in extremely premature babies. It is not possible for someone who does not have experience in this field to do this operation. In addition, since the surgical procedure requires a certain period of time, the patient may worsen during the procedure. In order to eliminate the disadvantages of tube thoracostomy, it is possible to evacuate the air in the pleural space with a simple method, especially in the treatment of neonatal pneumothorax by using a branula.
\end{abstract}

Keywords: Newborn, pneumothorax, treatment, minimally invasive surgery

\section{ÖZ}

\section{Yenidoğan Hastaların Pnömotoraks Tedavisinde Anjiyokateter ve Toraks Tüpünün Karşılaştırılması}

Amaç: Hayatı tehdit eden acil durumlardan biri olan pnömotoraksta erken tanı ve uygun tedavi komplikasyonları ve mortaliteyi azaltmak için önemlidir. Tedavi, iğne torasentez veya ince kateter ve tüp torakostomi teknikleri kullanılarak su altı drenaj ile plevral boşluktan havanın boşaltılması ile sağlanır.

Gereç ve Yöntemler: Mart 2014-Mart 2021 tarihleri arasında yenidoğan yoğun bakım ünitesi tıbbi kayıtları geriye dönük olarak incelendi ve pnömotoraks gelişen veya bu tanı ile hastaneye yatırılanlar değerlendirildi. Drenaj yöntemleri, tedavi süresi, tedavi etkinliği ve komplikasyonlar hakkında bilgi elde edildi. Çalışmada hastalar iki gruba ayrıldı. Birinci gruptaki hastalara göğüs tüpü, ikinci gruptaki hastalara venöz kateter yerleştirildi.

Bulgular: Yenidoğan yoğunbakım ünitemizdeki 1242 hastanın \%1,85'inde $(n=23)$ pnömotoraks saptandı. Sekiz hastaya tüp torakostomi ve 12 hastaya venöz kateter ile su altı sızdırmaz drenaj uygulanırken, üç hastada kendiliğinden düzeldi. Sonuç: Neonatal pnömotoraksta tedavinin amacı plevral boşluktaki havayı boşaltmak ve solunum desteği sağlamaktır. Tüp torakostomi küçük hastalarda özellikle aşırı prematüre bebeklerde ciddi komplikasyonlara yol açabilir. Bu alanda deneyimi olmayan birinin bu işlemi yapması mümkün değildir. Ayrıca cerrahi işlem belirli bir süre gerektirdiğinden işlem sırasında hastada kötüleşme olabilir. Tüp torakostominin dezavantajlarını ortadan kaldırmak için özellikle yenidoğan pnömotoraks tedavisinde branül kullanılarak plevral boşluktaki havanın basit bir yöntemle boşaltılması mümkündür. Yenidoğanlarda yöntemin kendisi hızlıdır ve plevral boşluktaki havanın branül ile boşaltılması da hızlıdır. Anahtar Kelimeler: Yenidoğan; pnömotoraks; tedavi; minimal invazif cerrahi 


\section{INTRODUCTION}

Pneumothorax, one of the life-threatening emergencies, is more common in the neonatal period compared to other periods of childhood. Symptomatic pneumothorax may be encountered in $0.08 \%$ of all live births. Although its incidence is reported as $1-2 \%$ in all newborns and $5-7 \%$ in those with a birth weight below $1500 \mathrm{~g}$, it has been reported to increase up to $30 \%$ in those with underlying lung problems and those who need mechanical ventilation $(1,2)$. Pneumothorax, which is frequently encountered in neonatal intensive care units (ICU), is one of the causes of high mortality and morbidity especially in premature infants (3). Early diagnosis and appropriate treatment are important to reduce complications and mortality.

Treatment consists of the evacuation of air from the pleural space with underwater sealed drainage using needle thoracentesis or fine catheter and tube thoracostomy techniques. Classically, in patients with symptomatic pneumothorax, air leakage in the pleural space is corrected by tube thoracostomy. In this study, we aimed to evaluate the advantages and disadvantages of underwater sealed drainage with angiocatheter compared to thoracic tube placement in the treatment of pneumothorax in newborn patients.

\section{MATERIAL AND METHODS}

Neonatal ICU medical records were reviewed retrospectively between March 2014 and March 2021, and those who developed pneumothorax or were hospitalized with this diagnosis were evaluated. Information about drainage methods, treatment duration, treatment efficacy, and complications were obtained from patient records. The study was carried out with the approval of the ethics committee (2021/131).

In the study, the patients were divided into two groups. A chest tube was placed to drain the leaky air in the patients in the first group, and a venous catheter (18-gauge) was inserted instead of the thorax tube in the patients in the second group. In our service, the chest tube was inserted in all patients at the beginning and the venous catheter method was used in the later period.

A 12 French standard thoracic tube was used in group I patients for tube thoracostomy. After cleansing the skin with povidone-iodine, local anesthesia (lidocaine hydrochloride) was applied and a small incision was made in the fifth intercostal space on the right or the sixth on the left. Using a blunt-tipped instrument, the surgeon created a subcutaneous tunnel by separating the intercostal muscle fibers and inserted the catheter into the thoracic cavity, crossing the pleura. The catheter was connected to an underwater drainage system and secured to the skin with nonabsorbable sutures. An assistant surgeon and nurse were needed during the procedure.

For group II, the surgeon used an 18 gauge, $45 \mathrm{~mm}$ long venous catheter to treat patients' pneumothorax. After cleaning the skin with povidone-iodine without applying local anesthesia, the catheter was put into the fifth intercostal space on the midclavicular line in boys and the anterior axillary line in girls. After feeling that the chest wall had been passed, the guide needle was withdrawn slightly and the catheter was directed towards the upper part of the chest cavity. After the guide needle was removed, the catheter was immediately connected to the underwater drainage system via a serum set. The position of the catheter was made sure by oscillation, and it was fixed to the skin with a transparent bandage without suturing. The entire procedure was performed in the patient's incubator without transplant or relocation. Only one nurse was needed for assistance. The instruments to be used in this procedure were an 18 gauge venous catheter and an underwater drainage system consisting of a serum set and bottle that can be easily found in every ICU (figure 1).

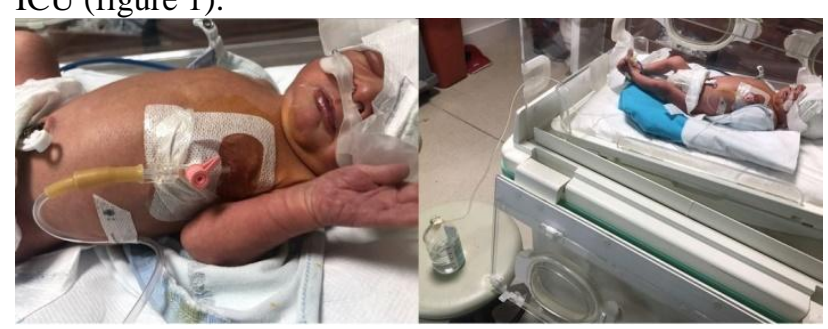

Figure 1. Treatment of pneumothorax with venous catheter technique in a patient in the intensive care unit

A chest X-ray was taken soon after the procedure to confirm the currency of the treatment in both groups. When clinical improvement occurred or when the bubbling in the system stopped, the absence of leakage air was again proved by film and the drainage system was clamped. The chest tube or venous catheter was then removed when a final chest X-ray, taken after the underwater drainage system was closed for 6 hours, showed no further air leaks. In Group I patients, the wound was closed with a previously placed fixation suture immediately after catheter removal, and then cleaned for 3 days and dressed with povidone-iodine. Stitch removal was performed on the 7th day. In the angiocath group, the access site was preserved with a little sterile bandage for only 1 day after the catheter was removed.

\section{RESULTS}

Pneumothorax was detected in $1.85(n=23)$ of 1242 patients who were followed up and treated in our neonatal ICU between March 2014 and March 2021. 60.8\% (n:14) of the patients were male and $39.2 \%(n=9)$ were female. The mean body weight was $2342.8 \pm 1042.3$ g (748-3585 g). The mean gestational age was $34.1 \pm 5.1$ weeks $(25-40$ weeks).

There were right pneumothoraxes in 18 patients, left pneumothorax in three patients, and bilateral involvement in two patients. Eight patients underwent tube thoracostomy and 12 patients underwent underwater sealed drainage with a venous catheter, while in three patients the pneumothorax resolved spontaneously without surgical intervention. Re-intervention was performed due to tube dislocation in one patient and iatrogenic pneumothorax after tube removal in one patient and tube thoracostomy. In two of the patients who underwent underwater drainage with a branule, the procedure was repeated because the catheter was bent at the junction and did not oscillate. Two patients followed up for pneumothorax (one with tube thoracostomy and the other treated with angiocatheter) died of congenital causes. 


\section{DISCUSSION}

Pneumothorax, which occurs when air collects in the pleural space (between the parietal and visceral pleura), is the most common air leakage. Pneumothorax is more common in newborns (1-2\%) than in older children (1.2$28 \%$ per 100,000 ), and this rate may increase up to $30 \%$ in patients with concomitant underlying lung disease or lung disease requiring mechanical ventilation and is especially seen in the first three days of life $(1,4,5,6)$. Early diagnosis and treatment of neonatal pneumothorax are vital to prevent complications and decrease mortality from hypoxia, hypercapnia, or disrupted venous return.

The increased intrathoracic pressure with high-tension pneumothorax not only causes respiratory distress by pressing on the lungs, but also causes an increase in central venous pressure and a decrease in venous return. As a result, cardiac output decreases (7), hypotension, bradycardia develop, and the risk of intraventricular bleeding increases (8). Pneumothorax can result in death if not treated promptly. In studies previously published in our country, it was reported that the mortality rate could reach $38.6 \%$ (9-12). In our study, the mortality rate was found to be $8.69 \%$.

The aim of treatment in neonatal pneumothorax is to drain the air in the pleural space and to provide respiratory support. Options include a variety of approaches, including clinical observation ('wait and see'), simple needle aspiration (thoracentesis), or insertion of an intercostal chest tube.

Thoracostomy is classically performed by inserting a chest tube (10 or 12 French) into the pleural space. After the skin in the operation area is cleaned with an antiseptic solution, a local anesthetic (such as lidocaine solution) is applied to the subcutaneous tissues and intercostal area, and so analgesia is provided. After a small midaxillary incision on the skin at the level of the fifth intercostal space, the subcutaneous tissue is dissected and a pathway is made just below the rib, reaching the thoracic cavity. The chest tube is routed to the location of the pneumothorax and secured to the skin with nonabsorbable sutures, then connected to a Heimlich valve or an underwater drainage system.

Tube thoracostomy can lead to serious complications in small patients, especially in extremely premature babies (3). As a result, chest tube placement in newborns is a surgical procedure as in adults. The most common complications are listed in Table 1.

Table 1. Common complications of tube thoracostomy in the treatment of neonatal pneumothorax

Minor complications
Hemorrhage from incision
Torsion of chest tubes
Suffering from pain during breathing
Subcutaneous emphysema
Worse appearance of the scar
Major complications
Hemothorax because of rupture of intercostal
vessels
Air leak at the incision site
Emphysema
Lung perforation
Abscess at insertion site
Inadvertent dislocation or removal of the chest
tube
Iatrogenic pneumothorax during or after tube
removal

It is not possible for someone who does not have experience in this field to perform this procedure. Complications such as lung tissue injury and diaphragm damage may develop during tube thoracostomy (9). Also, since the surgical procedure requires a certain amount of time, the patient may deteriorate during the procedure.

Most of the problems are related to the size of the instruments used and the incompatibility of the baby with the narrow intercostal space, and this can cause vascular damage during the procedure. Soft tissue dissection is not required for the placement of trocar chest tubes. It is also easy to direct it in the desired direction, but there is a risk of injury to the underlying organs $(13,14)$. When used correctly, it is effective and practical, especially in the treatment of spontaneous pneumothorax $(15,16)$. Another less traumatic method is the insertion of pigtail catheters using the small (8 or 10 French) Seldinger technique, which is generally more suitable for preterm infants (17). However, this method should be done in experienced hands and it is not exempt from the disadvantages listed above, except for vascular injury.

In order to eliminate the disadvantages of tube thoracostomy, it is possible to evacuate the air in the pleural space by using a branule with a simple method, especially for the treatment of neonatal pneumothorax (Table 2).

Underwater drainage with branule is an easy and simple procedure. After the intervention area is cleaned with aseptic agents, a branule is placed in the chest cavity under sterile conditions. It is essential that the venous catheter used is of sufficient thickness and length to reach the chest cavity and aspirate the leaky air. The needle is then withdrawn from the guide tube, connected to the underwater sealed chest drainage system, and fixed with plasters or adhesive tapes after the oscillation is seen. In newborns, the method itself is fast, and the evacuation of the air in the pleural cavity with the branule is also fast.

In 23 patients, leakage in the pleural space was corrected using an 18-gauge angiocatheter with this method. These catheters are unlikely to be bent in the thoracic cavity, but if they are not fixed well, they may bend under the skin due to the flexible skin of babies, leading to the failure of the procedure. Apart from this complication, which we encountered in two of our patients and which we corrected immediately due to the absence of oscillation, no complications related to the method were observed in our patients. In the chest X-ray taken 1 hour after the branule was placed, it was determined that the air in the pleural cavity was completely or almost completely evacuated. The oscillation disappeared after an average of 36 hours. Drainage was terminated according to the chest $\mathrm{X}$-ray taken after the system was closed with a four-hour clamp.

Accidental dislocation of the chest tube can cause iatrogenic pneumothorax or air leak. These problems usually occur when tube fixation is inadequate or when there is a problem with wound healing. The handicap of the relatively short subcutaneous tunnel prepared for chest tube placement in newborns, it is easy to dislodge the tube if fixation is not done well or accidentally. When using a venous catheter, this should never be a problem as the skin entry area is only as wide as 18 grooves. Because this small wound is closed immediately, iatrogenic 
Table 2. Advantages and disadvantages of angiocatheter and thorax tube in the treatment of pneumothorax in newborn patients

\begin{tabular}{|c|c|c|}
\hline & Angiocatheter & Thorax Tube \\
\hline \multirow[t]{11}{*}{ Advantages } & Easier to learn, no surgical experience required & Can also be applied to obese babies \\
\hline & Can be applied in a short time & It can also be used in case of intrathoracic infection \\
\hline & Complication rate is less & Provides adequate discharge even in large leaks \\
\hline & Less surgical stress & \\
\hline & No surgical equipment required & \\
\hline & Does not require local anesthesia & \\
\hline & Re-insertion of catheter is easy & \\
\hline & Better cosmetic appearance & \\
\hline & Causes less pain & \\
\hline & Does not cause iatrogenic leakage even if accidentally removed & \\
\hline & No dressing required & \\
\hline \multirow[t]{9}{*}{ Disadvantages } & Can only be used for air leaks & Requires surgical experience \\
\hline & May be insufficient to drain large leaks & Requires surgical equipment \\
\hline & It can be bent easily if not fixed well. & Takes time to apply \\
\hline & Catheter length may be insufficient in large-birth-weight & Complication rate is relatively high \\
\hline & neonates & Causes pain and surgical stress \\
\hline & & Local anesthesia is essential \\
\hline & & It is difficult to reposition \\
\hline & & $\begin{array}{l}\text { It is difficult to adjust the tube size in small } \\
\text { premature patients }\end{array}$ \\
\hline & & Requires post-tube care and monitoring \\
\hline Contraindications & Intrathoracic infection & Bleeding diathesis \\
\hline
\end{tabular}

pneumothorax is not a major problem even if the catheter is accidentally removed.

Thoracostomy with a chest tube is a procedure that requires more detailed surgical techniques, and the small size of the patient makes surgical skill more important. Any procedure to the patient can cause surgical stress that can complicate the situation, and this is a critical consideration for the newborn struggling with other serious underlying pathologies. We found the venous catheter technique to be much simpler than thoracostomy in many young patients in the ICU. A simple air drainage system consisting of a venous catheter, an serum set, and a glass bottle of water are all necessary equipment. The procedure is an easy, bedside procedure with the help of a nurse: the catheter is inserted without local anesthesia, fixed, and then connected to this underwater drainage system, and the entire procedure takes much less time than placing a chest tube (18). Our experience clearly shows that venous catheter therapy for pneumothorax causes minimal patient stress compared to tube thoracostomy.

In a study that reported a $30 \%$ mortality rate, they reported that chest tube insertion and thoracentesis had negative effects on mortality in newborns with pneumothorax (19). In another study, it was reported that there was no significant difference between angiocatheter and tube thoracostomy and underwater drainage in terms of mortality and complication rates, but underwater sealed drainage with an angiocatheter was easier, less invasive, and less time-consuming $(20,21)$.

The limitations of this study are as follows, and a welldesigned multi-institutional observation study is needed to address this issue further: the small sample size and difficulties in data collection like the lack of procedure time.
In conclusion, we think that the treatment of pneumothorax with a venous catheter instead of a thoracic tube is a relatively easy and much less invasive bedside method, especially in newborn patients. Even in extremely small premature babies who require urgent aspiration, placing of this catheter is quite simple and successfully corrects pneumothorax even in small patients. In addition, potentially serious complications related to tube thoracostomy are not usually seen with this procedure.

\section{Financial Resource}

No financial resources have been used for this article.

\section{Conflict of Interest}

There is no conflict of interest regarding this article.

Authors's Contributions: Idea/Concept: M.K.; Design: M.K., M.K.; Data Collection and/or Processing: M.K., M.K.; Analysis and/or Interpretation: M.K., M.K.; Literature Review: M.K.; Writing the Article: M.K.; Critical Review: M.K., M.K.

\section{REFERENCES}

1. Litmanovitz I, Carlo WA. Expectant management of pneumothorax in ventilated neonates. Pediatrics. 2008; 122: 975-9.

2. Malek A, Afzali N, Meshkat M, Yazdi NH. Pneumothorax after mechanical ventilation in newborns. Iran J Pediatr. 2011; 21: 45-50.

3. Bhatia R, Devis PG, Doyle LW, Wong C, Morley CJ. İdentification of pneumothorax in very preterm infants. J Pediatr. 2011; 159: 115-20.

4. Irving IM. Malformations and acquired lesions of lungs, pleura, and mediastinum. In: Lister J, Irving IM editor (s). Neonatal Surgery. 3rd Edition. London: Butterworths, 1990: 259-79. 
5. Seguier-Lipszyc E, Elizur A, Klin B, Vaiman M, Lotan G. Management of primary spontaneous pneumothorax in children. Clin Pediatr (Phila). 2011; 50(9): 797-802.

6. Ogino MT: Pulmonary air leak. In: Manual of Neonatal Care, 5th edn (Cloherty JP, Eichenwald EC, Stark AR, eds). Lippincott, Williams \& Wilkins, 2004; pp 371-7.

7. Fernandes CJ. Pulmonary air leak in the newborn. In: UpToDate, Basow, DS (Ed), UpToDate, Waltham, MA, 2014.

8. Pishva N, Parsa G, Saki F, SakiM, SakiMR. Intraventricular hemorrhage in premature infants and its association with pneumothorax. Acta Medica Iranica. 2012; 50(7): 473-6.

9. Apiliogullari B, Sunam GS, Ceran S, Koc H. Evaluation of neonatal pneumothorax. J Int Med Res. 2011; 39: 2436-40.

10. Ali R, Ahmed S, Qadir M, Maheshwari P, Khan R. Pneumothoraces in a neonatal tertiary care unit: case series. Oman Med J. 2013; 28: 67-9.

11. Ilçe Z, Gündogdu G, Kara C, Ilikkan B, Celayir S. Which patients are at risk? Evaluation of the morbility and mortality in newborn pneumothorax. Indian Pediatr. 2003; 40: 325-8.

12. Özbek AS, Kavuncuoğlu S, Ugan AS, Aldemir EY, Payasl1 M, Sander S. 2004-2008 Yillar1 arasinda yenidoğan yoğun bakım ünitesinde pnömotoraks tanısıyla izlenen olguların incelenmesi. JOPP Derg. 2011; 3: 79-85.

13. Hyde J, Sykes T, Graham T. Reducing morbidity from chest drains. BMJ. 1997; 314: 914-5.

14. Millikan JS, Moore EE, Steiner E, Aragon GE, Van Way CW. 3rd Complications of tube thoracostomy for acute trauma. Am JSurg. 1980; 140: 738-41.

15. Gregoire J, Deslauriers J. Surgical techniques in the pleura. Closed drainage and suction systems. In: Pearson FG, Cooper JD, Deslauriers J, Ginsberg RJ, Hiebert CA, Patterson GA, Urschel HJ. Thoracic Surgery. 2nd Edition. New York, Churchill Livingston. 2002, p.1281-1300.

16. Yildizeli B, Yüksel M. Plevra hastalıklarında cerrahi teknikler. Toraks Dergisi. 2002; 3: 27-41.

17. Cloherty JP, Eichenwald EC, Stark AR. Pulmonary air leak. Manual of Neonatal Care. 7th Edition. Lippincott Williams \& Wilkins, 2011.

18. Katar S, Taşkesen M. Yenidoğan pnömotorakslı hastalarda anjiyocat ile sualtı drenajının toraks tüpüne göre değerlendirilmesi. Güncel Pediatri. 2019; 17(1): 151-6.

19. İris SS, Filipa FL, Gustavo R, Ines A, Hecilia G. Pneumothorax in neonates: a level III neonatal 1ntensive care unit experience. Journal of Pediatric and neonatal Individualized Medicine. 2016; 5: 1-8.

20. Bruschettini M, Romantsik O, Ramenghi LA, Zappettini S, O’Donnell CPF, Calevo MG. Needle aspiration versus intercostal tube drainage for pneumothorax in the newborn. Cochrane Database of Systematic Reviews. 2016; 1: 1-28.

21. Arda IS, Gürakan B, Aliefendioğlu D, Tüzün M. Treatment of pneumothorax in newborns: use of venous catheter versus chest tube. Pediatr Int. 2002; 44(1): 78-82. 